\title{
揮発性硫黄化合物測定器ハリメーター®を用いた 口臭測定の検討
}

$\begin{array}{cccc}\text { 佐 藤 修一 } & \text { 大森みさき } & \text { 村山恵子 } & \text { 中村貴文 } \\ \text { 斎 藤 光博 } & \begin{array}{c}\text { 今 井 理 江 堀 玲子 } \\ \text { 日本歯科大学新潟歯学部歯周治療学教室 }\end{array} & \\ & (1999 \text { 年 } 4 \text { 月 } 10 \text { 日受理 }) & \end{array}$

\author{
A Study of Measurement of Oral Malodor with \\ a Portable Sulfide Monitor Halimeter ${ }^{\circledR}$ \\ Shuichi Satoh, Misaki Ohmori, Keiko Murayama, Takafumi Nakamura, \\ Mitsuhiro Saitoh, Rie Imai, Reiko Hori and Akira Hasegawa \\ Department of Periodontics, The Nippon Dental University School of Dentistry at Niigata \\ Accepted for publication 10 April 1999
}

The purpose of this study was to assess the usefulness of a portable sulfide monitor (Halimeter ${ }^{\circledR}$ Model RH 17 E, Interscan, U.S.A.), and to examine the relationship with oral malodor and periodontal indices.

One hundred and one healthy adults, students and staff of The Nippon Dental University School of Dentistry at Niigata, were measured for oral malodor using a portable sulfide monitor and organoleptic examination.

After that, thirteen individuals were examined, for whom periodontal indices (probing depth (PD), plaque control record (PCR), plaque index (PII), and bleeding on probing (BOP)) were compared with oral malodor.

The result showed that the organoleptic scores overlapped with volatile sulfur compound values. However, the organoleptic scores were correlated with volatile sulfur compound values.

These results suggest that this portable sulfide monitor may be useful as a chair-side measurement of oral malodor. However, no correlation was found between volatile sulfur compound values and periodontal indices. J. Jpn. Soc. Periodontol., 41 : 195 200, 1999.

Key words : oral malodor, volatile sulfur compound, organoleptic score, portable sulfide monitor

要旨：日本歯科大学新潟歯学部の学生および職員から無作為に抽出した 101 名に対し, 口腔内の揮発性硫黄化

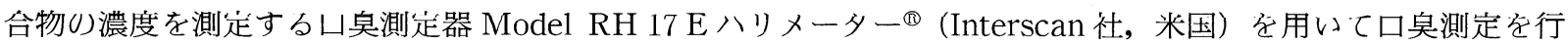
い，口臭の官能試験と比較することにより，その有用性について検討した。また，同意の得られた者 13 名に対 し口腔内診査を行い，口臭と臨床的パラメータの関連についても検討を行った。その結果，

1）官能評価值に対するハリメーター值の範囲に重複が認められるため, ハリメーターのみで口臭の程度を判 別することは困難であると思われたが, 官能評価值とハリメーター值は対応する傾向があり, 本口臭測定器は チェアーサイドにおいて使用しうると考えられた。

2）臨床的パラメータとハリメーター值はすべての指標において相関関係は有意ではなかった。

索引用語: 口臭, 揮発性硫黄化合物, 官能試験, 口臭測定器 


\section{緒言}

口臭の判定は，日常，官能試験によって行われてい るが, 嗅覚は特殊な感覚であり疲労, 誤認を起こしや すく，嫌な臭い，強い臭いなどというように主観的な 表し方にならざるを得ず，検査者の精神状態や健康状 態に影響されるという欠点がある。分析機器の開発, 発展により，ガスクロマトグラフィによって臭気物質 の性状，濃度，質量が定性，定量できるようになり， Tonzetich ${ }^{1)}$ は口臭成分として，揮発性硫黄化合物の 検出に成功している。しかしこのガスクロマトグラ フィによる方法は限られた施設でのみ可能であり一般 的な方法ではないため, 小型, 廉価の口臭測定器が求 められる。

一方で，口臭に関与すると思われる口腔内の状態に ついて調査した研究も報告されてきた。すなわち，海 津 $^{2}$ は辺縁性歯周炎患者の多くに口臭が認められ，ま た歯周炎に罹患していなくとも，舌苔が多く沈着した 者には口臭が認められることを示し，揮発性硫黄化合 物の発生源として歯周ポケットと舌苔が主要なものと 報告している。

そこで今回われわれは，被験者に対し，複数歯科医 師の嗅覚によって呼気の口臭を官能的に判定するとと もに，ガスクロマトグラフィに比べ，小型で簡便なロ 臭測定器 Model RH 17 Eハリメーター (Interscan 社，米国，以下ハリメーター) を用いて口腔内気体の 揮発性硫黄化合物の濃度を測定し，その有用性につい て検討した。さらに，同意の得られた者については，

\section{表 1 口臭強度の判定基準}

\begin{tabular}{ll}
\hline 0 & 口臭が認められないもの \\
1 & わずかに口臭が認められるもの \\
2 & 明らかに口臭が認められるもの \\
\hline
\end{tabular}

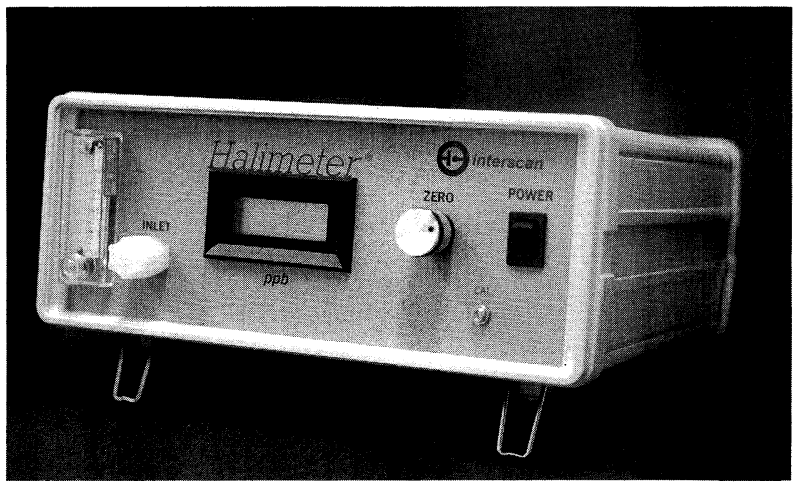

図 1 Model RH 17 Eハリメーター ${ }^{\circledR}$
口臭と関係があると思われる口腔内の状態についても 診査を行い，その相互関係について検討した。

\section{材料および方法}

研究 1. 口臭の官能試験とハリメーターによるロ臭 測定の相関関係

1. 対象

日本歯科大学新潟歯学部に在籍する学生および勤務 する職員で, 本研究の主旨に賛同を得た 101 名（男性 61 名，女性 40 名，平均年齢 $23.7 \pm 2.5$ 歳）を対象と した。

口臭の官能試験とハリメーターによる口臭試験は, 室温 $27 \sim 28^{\circ} \mathrm{C}$, 測定時刻 $14 \sim 18$ 時で行った。

\section{2. 問診}

疾病の既往歴と現症, 薬の服用の有無と種類, 診査 前に最も近く飲食, 歯磨き, 洗口などを行った時間, 喫煙の有無，1 日のブラッシング回数，1 回のブラッ シング時間および歯ブラシ以外の口腔清掃用具の使用 の有無について問診を行った。調査対象 101 名のう ち, 現在, 歯科疾患以外の各種疾患で治療を受けてい る者，抗生物質を服用している者および当日食事をと らなかった者の 16 名は対象から除外した。

\section{3. 口臭の官能試験}

官能試験は, 被験者の口から約 $50 \mathrm{~cm}$ 離れた検査 者に対し息を吹きかけさせて行った。口臭の強度の判 定は, 3 名の歯科医師が検査者となって行い, 呼気中 に不快な臭いが感じとられたものすべてを口臭とし， その判断は各検査者の主観に任せた。判定基準は 0 か ら 2 までの 3 段階で評価し（表 1)，2 名以上が一致し た値を個人の值（以下官能評価値）とした。

\section{4. ハリメーターによるロ臭測定}

ハリメーターは内部のポンプによってロ腔内気体を

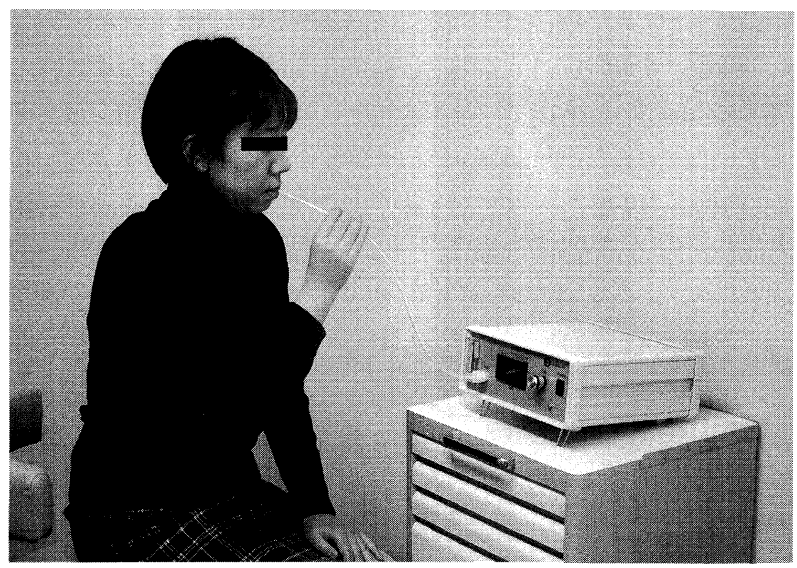

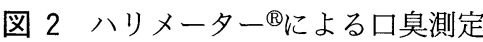


自動的に吸引し，内蔵センサーによって測定された揮 発性硫黄化合物量を液晶パネルに ppb 単位で表示す る（図 1)。測定前にハリメーターの 0 調節を行い, 被験者には椅子に腰掛けた状態で 1 分間鼻呼吸をさせ 安静を保たせた。ハリメーターの空気導入口にプラス チックホースをセットし，その先端に各被験者ごとに 直径 $6 \mathrm{~mm}$, 長さ $20 \mathrm{~cm}$ のプラスチックチューブを接 続した。被験者に鼻呼吸をさせたままの状態で口をわ ずかに開けさせ，プラスチックチューブを口腔内に 4 $\mathrm{cm}$ 挿入した（図 2)。液晶パネルに表示される測定值 は, 測定開始から徐々に上昇し, 約 9 12 秒後に安定 を示す。測定は測定值が安定を示すところまで行い, 測定中の最高値を個人の值（以下ハリメーター值）と した。なお，測定は各被験者ごとに 1 回かぎり行っ た。

研究 2. 臨床的パラメータとハリメーター値の相関 関係

\section{1. 対象}

研究 1 における対象者のうち，本研究の主旨に賛同 を得た 13 名（男性 9 名，女性 4 名，平均年齢 $25.5 \pm$ 3.1 歳）を対象とした。

2. ハリメーターによるロ臭測定

研究 1 の方法に準じて測定した。

\section{表 2 舌苔付着度の分類}

\begin{tabular}{ll}
\hline 0 度 & 舌苔付着を認めないもの \\
1 度 & 舌苔付着範囲 $1 / 3$ 程度の薄い舌苔 \\
2 度 & 舌苔付着範囲 $2 / 3$ 程度の薄い舌苔, もしくは舌苔 \\
& 付着範囲 $1 / 3$ 程度の厚い舌苔 \\
3 度 & 舌苔付着範囲 $2 / 3$ 程度以上の薄い舌苔, もしくは \\
& 舌苔付着範囲 $2 / 3$ 程度の厚い舌苔 \\
4 度 & 舌苔付着範囲 $2 / 3$ 程度以上の厚い舌苔 \\
\hline
\end{tabular}

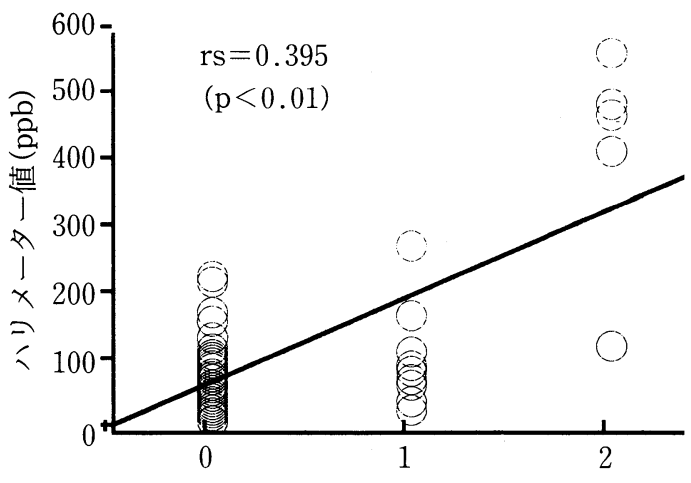

官能評価値

図 3 官能評価值とハリメーター值との相関

\section{3. 口腔内診査}

1) 歯周診査

(1) プラークの診査

プラークの付着面は, O'Leary ら³の Plaque Control Record (以下 PCR) に準じて各歯 6 点法（煩側 近心，煩側中央，煩側遠心，舌側近心，舌側中央，舌 側遠心）で測定した。また，プラークの量について は, Silness \& Löe ${ }^{4)} の$ Plaque Index（以下PlI）に 準じて各歯 6 点法で測定した。

(2) Probing Depth (以下 PD)

$\mathrm{PD}$ の測定は, 日本歯科大学新潟式プローベ (YDM, 東京) ${ }^{5)}$ を使用し, 各歯 6 点法により $1 \mathrm{~mm}$ 単位で測定した。

(3) Bleeding on Probing (以下 BOP)

歯肉の炎症の指標として BOP の測定を行った ${ }^{6)}$ 。 BOP の測定は PD を測定した際の，歯周ポケットか らの出血の有無を各歯 6 点法で測定した。

2) 舌苔付着の診査

舌苔付着の評価は，小島7)の方法に準じて舌苔付着 範囲（舌体部に対する舌苔付着の割合）と舌苔の厚さ を考慮し，0 度から 4 度までの 5 段階で評価した（表 2)。

\section{統計学的検索}

官能評価值とハリメーター值との相関関係，および 臨床的パラメータとハリメーター值との相関関係につ いては Spearman 順位相関係数を用いた。また，官 能評価值別のハリメーター值の比較，および問診項目 別のハリメーター值の比較についてはMannWhitney's U-test を用いた。

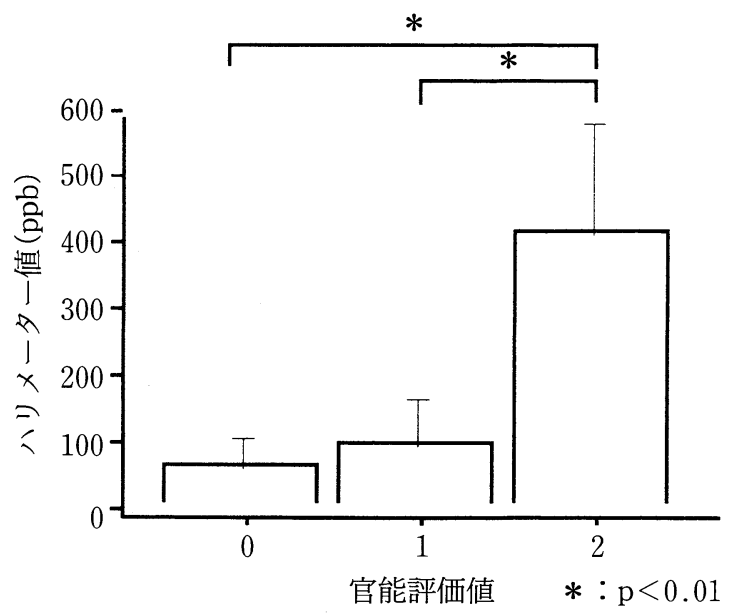

図 4 官能評価値別のハリメーター値 
表 3 問診項目別ハリメーター值

\begin{tabular}{|c|c|c|c|}
\hline \multirow{2}{*}{ 指標 } & \multirow{2}{*}{ 分類 } & \multirow{2}{*}{ 人数 } & ハリメーター值 \\
\hline & & & Mean \pm S.D. \\
\hline \multirow[t]{2}{*}{ 性別 } & 男性 & 53 & $97.4 \pm 120.0$ \\
\hline & 女性 & 32 & $83.6 \pm 60.6$ \\
\hline \multirow[t]{2}{*}{ 喫煙の有無 } & 有 & 33 & $58.7 \pm 31.6 \neg$ \\
\hline & 無 & 52 & $113.4 \pm 123.2 *$ \\
\hline \multirow[t]{2}{*}{ ブラッシング } & 2 回以下/日 & 60 & $88.2 \pm 104.2$ \\
\hline & 3 回以上/日 & 25 & $101.9 \pm 96.4$ \\
\hline \multirow{2}{*}{$\begin{array}{l}\text { 歯ブラシ以外の口腔清掃用具 } \\
\text { の使用の有無 }\end{array}$} & 有 & 15 & $88.1 \pm 62.0$ \\
\hline & 無 & 70 & $93.1 \pm 108.5$ \\
\hline
\end{tabular}

表 4 臨床的パラメータとハリメーター值との Spearman の順位相関係数 $(\mathrm{n}=13)$

\begin{tabular}{lcc}
\hline 指標 & Spearman の順位相関係数 & $\mathrm{p}$ \\
\hline PCR & 0.253 & 0.381 \\
PII & 0.333 & 0.249 \\
PD & 0.316 & 0.274 \\
BOP & 0.423 & 0.143 \\
\hline
\end{tabular}

結果

研究 1. 口臭の官能試験とハリメーターによるロ臭 測定の相関関係

官能評価值 0 の者は 69 名 $(81.2 \%) ， 1$ の者は 11 名 $(12.9 \%) ， 2$ の者は 5 名 $(5.9 \%)$ であり，低い官 能評価值の被験者が多かった。官能評価值とハリメー ター値の相関を図 3 に示す。 $r s=0.395 （ \mathrm{p}<0.01 ）$ の 弱い正の有意相関が認められた。全被験者のハリメー ター値（最小值〜最大值）は $92.2 \pm 101.6 \mathrm{ppb（18～}$

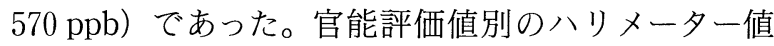
を図 4 に示す。官能評価值 0 の者が $67.2 \pm 43.7 \mathrm{ppb}$ (18２35 ppb)，官能評価值 1 の者が $100.7 \pm 70.6$ $\mathrm{ppb}(35 \sim 278 \mathrm{ppb})$, 官能評価值 2 の者が $417.6 \pm$ $168.8 \mathrm{ppb}(131 \sim 570 \mathrm{ppb})$ で官能評価值が 0 と 2,1 と 2 のそれぞれの間に有意差を認めた（ $\mathrm{p}<0.01 ） 。$

問診項目別に分けたハリメーター值を表 3 に示す。 男女間，歯ブラシ以外の口腔清掃用具の使用の有無に よるハリメーター値の違いは認められなかった。1日 のブラッシング回数により対象者を，2 回以下と 3 回 以上の 2 つ群に分けてハリメーター值を比較した が，有意差は認められなかった。また，喫煙の有無で の比較については, 喫煙者のほうが非契煙者よりハリ メーター值が有意に低かった（p<0.05）。

研究 2. 臨床的パラメータとハリメーター值の相関 関係

臨床的パラメータとハリメーター值との相関を表 4 に示す。今回の研究では，すべての指標において危険 率 $5 \%$ で有意ではなかった。

舌苔付着については，1 度の付着例を 1 名認めたの みであった。この被験者の官能評価值は 2 , ハリメー ター值は $475 \mathrm{ppb}$ と高值を示した。他の 12 名につい ては舌苔を認めなかった。

\section{考 察}

ハリメーターは歯科におけるチェアーサイドで簡易 に口臭を測定するために開発された装置である。ハリ メーターによるロ臭測定は，ガスクロマトグラフィと 異なり，定性分析を行うことはできないが，口臭の主 たる原因とされるメチルメルカプタンなど，揮発性硫 黄化合物の総量を定量することができる。本装置の特 徵は，スイッチを入れてから測定可能になるまでの時 間が約 2〜3 分, 連続使用時の待ち時間が約 2 分と短 いことや低コストであることである。また，本体は $3.4 \mathrm{~kg}$ と軽量であり，幅 $25.5 \mathrm{~cm}$ ，奥行き $26.5 \mathrm{~cm}$, 高さ $11.5 \mathrm{~cm}$ と小さく，チェアーサイドで使用する には都合がよいと思われた。

研究 1 の結果, 官能評価值に対するハリメーター值 の範囲はそれぞれ広範囲に分布するため，ハリメー ターによる試験だけで口臭の程度を判別することは困 難であると思われた。官能試験法には呼気をバッグに 採取する方法 ${ }^{8}$ があるが，バッグに採取した場合，気 体のバッグ内面の吸着や分解などの経時的変化を考慮 しなければならない。また，本研究の対象が口臭患者 
ではないために低い口臭の強度で判定をしなければな らないことが予想されたため, 今回は新鮮な呼気を判 定できる利点を考慮し, 被験者が検査者に直接息を吹 きかける方法を用いた。この方法は複数名の検査者が 判定を行う場合, 被験者から吐き出される呼気がその 都度同一の量, 同一の勢いでない可能性があり判定結 果がばらつく原因となり得るので, 検査者 3 名中 2 名 以上が一致した值を採用することで補うこととした。 口臭強度の判定基準については, 官能評価值を 3 段階 に分類して口臭の官能試験を行ったが，その結果，生 理的口臭の判別が困難であり, 被験者の多くが口臭が 認められないものと判定され，また，明らかに口臭の 認められるものは人数が少なかった。

以上の条件における官能評価值とハリメーター值の 相関については, $r s=0.395 （ \mathrm{p}<0.01 ）$ の弱い正の有 意相関が認められた。これまでの報告では, 他のポー タブルサルファイドモニターを用いた研究でも, 官能

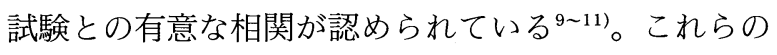
結果と嗅覚が疲労や誤認を起こしやすい特殊な感覚で あることを考慮し, 口臭の診査には官能試験と口臭測 定器を併用した判定が望ましいと思われた。

問診項目別に比較したハリメーター值では, 本研究 においてもこれまでの報告 ${ }^{12 \sim 14)}$ と同様に性差の影響 は認められなかった。また, 1 日のブラッシング回数 によるハリメーター值と歯ブラシ以外の口腔清掃用具 の使用の有無によるハリメーター值についても差が認 められなかった。喫煙の有無については, 夕バコの煙 自体に揮発性硫黄化合物が含まれている ${ }^{15}$ にも関わら ず，今回の結果でもこれまでの報告 ${ }^{16)}$ と同様に喫煙者 の方が非喫煙者に比べてハリメーター值が低い傾向 $(\mathrm{p}=0.023)$ が認められた。これまでに, 契煙者のほ うが非喫煙者に比べて歯周疾患の重症度が高いにもか かわらず，歯肉出血は少ないとの報告 ${ }^{17)}$ があり，この ことから, 歯肉出血の増加に伴い揮発性硫黄化合物も 増加している可能性があると考えられた。また，ハリ メーターは口腔内からのみ気体を採取するため測定直 前に喫煙しふい限り測定值に影響を与えないもUと推 測された。

口腔内の状態と揮発性硫黄化合物との関連を研究し た報告では，口臭の程度とプラーク量との相関は認め

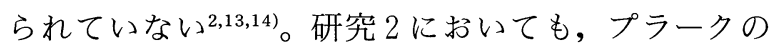
付着状態の診査を行っているが, PCR, PII ともに八 リメーター值との間に弱い相関関係を認めたが，有意 ではなかった。一方で, 多くの研究者がガスクロマト グラフィを用いた方法で歯肉炎や歯周ポケットと揮発 性硫黄化合物との相関を認めている ${ }^{2,12,18)}$ 。海津 ${ }^{2}$ は, 舌苔より歯周ポケットからの揮発性硫黄化合物産生の
ほうが大きいであろうと推測しているが，一方で歯周 ポケットの深さと口臭との間には相関関係は認めな かったと報告している。また, Bosy ら ${ }^{19)}$ は, 歯周ポ ケット由来の揮発性硫黄化合物は, 口腔内では相対的 に検出されにくいと報告している。今回の研究では, $\mathrm{PD}$ はハリメーター值との間に弱い相関関係を認め, BOP はハリメーター值との間に相関関係を認めたが, ともに有意ではなかった。

また，舌苔に関しては，Tonzetich ${ }^{18)}$ は舌苔を口臭 の発生源と断定しており, 安野ら ${ }^{20)}$ は口腔内揮発性硫 黄化合物と舌苔量との間に相関が認められたと報告し ている。今回の研究では, 1 度の舌苔付着例を 1 名認 めたのみであったため, ハリメーター值との相関関係 を調べることはできなかった。

今回の研究では, すべての指標においてハリメー ター值との相関関係は有意ではなかったが, 本研究の 対象が口臭を有する患者ではなく年齢的に若い健康な 成人であり，かなり低いレベルの揮発性硫黄化合物濃 度で口腔内状態との関連を見ているので, 過去の報告 と単純に比較することはできないと思われた。しかし ながら, 今回の結果は揮発性硫黄化合物発生は歯周組 織の状態だけに強く支配されているのではなく, 舌苔 あるいはその他の原因が複合した結果なのではないか と考えられた。

今回の結果, ハリメーターの測定值から口腔内の歯 周組織の状態を知ることは困難であると考えられた。 しかしながら, 官能評価值とハリメーター值との間に 弱い正の有意相関が認められたため, 病的な口臭を有 する者のスクリーニングや自臭症患者への対策として は有用ではないかと考えられた。

本論文の要旨は，1998 年 10 月 17 日 第 41 回秋季日本 歯周病学会学術大会において発表した。

\section{文献}

1) 'I'onzetich, J. : Direct gas chromatographic analysis of sulphur compounds in mouth air in man, Archs. Oral Biol., 16:587, 1971.

2）海津健樹：ガスクロマトグラフィーによるロ腔内揮 発性硫化物の分析. 日歯周誌, $18: 1-12,1976$.

3) O'Leary, T.J., Dranke, R.B. and Naylor, J.E. : The plaque control record. J. Periodontol., 43 : 38, 1972.

4) Silness, J. and Löe, H. : Periodontal disease in pregnancy. II. Correlation between oral hygiene and periodontal condition. Acta. Odontol., 22 : 121-135, 1964. 
5） 浜口茂雄：歯間部歯周ポケットとその測定法に関す る研究. 日歯周誌, 31：608-632, 1989.

6) Joss, A., Alder, R. and Lang, N.P. : Bleeding on probing. A parameter for monitoring periodontal conditions in clinical practice. J. Clin. Periodontol., $21: 402-408,1994$.

7）小島 健：舌苔の臨床的研究. 日口外誌, $31: 1659$ -1678, 1985.

8) Shimura, M., Yasuno, Y., Iwakura, M., Shimada, Y., Sakai, S., Suzuki, K. and Sakamoto, S. : A New Monitor With a Zinc-Oxide Thin Film Semiconductor Sensor for the Measurement of Volatile Sulfur Compounds in Mouth Air. J. Periodontol., $67:$ 396-402, 1996.

9) Rosenberg, M., Septon, I., Eli, I., Bar-Ness, R., Gelerter, I., Brenner, S. and Gabby, J. : Halitosis measurement by an industrial sulphide monitor. J. Periodontol., 62:487-489, 1991.

10）渡辺聡子，志村匡代，岩倉政城，押切邦中，井川恭 子, 楠本雅子, 坂本征三郎 : $\mathrm{ZnO}$ 薄膜センサを用 いた口臭測定器による測定値と官能評価値について の検討. 口腔衛生会誌，45：606-607, 1995.

11）角田正健, 渡辺裕作：口臭検知器の開発（第一報） 一原理と操作法一, 日歯周誌, 30：1128-1133, 1988.

12) Yaegaki, K. and Sanada, K. : Biochemical and clinical factors influencing oral malodor in periodontal patients. J. Periodontol., 63:783-789,
1992.

13）奈良文雄：口臭と歯周病患者における口腔内所見と の関係. 日歯周誌, $19: 100-108,1977$.

14）安野陽子：口臭の有病状況についての研究一農村地 区成人健診受診者における官能試験と質問紙調査の 比較. 東北大歯誌, 11：23-35, 1992.

15) Stedman, R.L.: The chemical composition of tobacco and tobacco smoke. Chem. Revs., 68: 153-207, 1968.

16）藤田智恵：口臭と唾液および歯周組織の健康状態に 関する疫学的研究. 九州歯会誌, $50 ： 976-988,1996$.

17) Ohmori, M., Murayama, K., Ishigami, H. and Hasegawa, A. : The effect of smoking on the response to periodontal non-surgical therapy. J. Nippon Dent. Univ., 2: 17-21, 1999.

18) Tonzetich, J. : Oral malodour: an indicator of health status and oral cleanliness. Int. Dent. J., 28:309-319, 1978.

19) Bosy, A., Kulkarni, G.V., Rosenberg, M. and McCulloch, C.A.G. : Relationship of oral malodor to periodontitis: evidence of independence in discrete subpopulations. J. Periodontol., $65: 37$ 46, 1994.

20）安野陽子, 岩倉政城, 島田義弘：口臭を訴える患者 の口内気体中揮発性硫黄化合物と症状との関係. 腔衛生会誌, 39：663-674, 1989.

\section{連絡先：}

日本歯科大学新潟歯学部歯周治療学教室

$\overline{\mathbf{T}} 951-8580$ 新潟市浜浦町 1-8 